\title{
Translation Analysis of Taxis in "The Old Man and the Sea" Novel (Systemic Functional Linguistics Approach)
}

\author{
Arso Setyaji \\ Universitas Sebelas Maret Surakarta, Indonesia \\ Sri Samiati Tarjana \\ Universitas Sebelas Maret Surakarta, Indonesia \\ M. R. Nababan \\ Universitas Sebelas Maret Surakarta, Indonesia \\ Tri Wiratno \\ Universitas Sebelas Maret Surakarta, Indonesia
}

\begin{abstract}
The Old Man and the Sea is a literature work by Ernest Hemingway. It has been translated into many languages even in Indonesian by Deera Army. Hemingway used more clause complex in producing his works. It causes problems in translation such as: translators should give more attention to the translation techniques used, readability decrease, and etc. On the other hand, Deera Army solved those problems by splitting the clause complex into shorter one. It is needed to conduct a study in how to make translation of complex clause. This study can be clearly conducted by using Systemic Functional Grammar (SFG) approach. In addition, this study is aimed at: (1) describing how can be interdependency and logical semantics of complex clause in source language realized into interdependency and logical semantics of complex clause in target language of The Old Man and the Sea Novel (2) describing what translation techniques on taxis markers are used in translating from source language to target language (3) describing translation quality of clause complex translation in target language. The result of the analysis showed that there are 400 sentences which have been broken into 701 clauses. Based on the analysis, there are paratactic and hypotactic form. Paratactic took $65.30 \%$ and hypotactic, $34.50 \%$. All of them affect translation quality. Based on the analysis, the average of accuration takes up 2.89 , naturalness with 2.96 and readibility with 2.97 . The writer suggests that the next researcher can conduct the same research in the deeper way.
\end{abstract}

Index Terms — hypotactic, logical-semantics, paratactic, taxis

\section{INTRODUCTION}

The Old Man and the Sea is a phenomenal literature work by Ernest Hemingway which tells the story of one's adventures and struggles in the Atlantic Ocean. This novel has achieved Politzer Prize in 1952 and Nobel Prize in 1954. There are many moral messages that can be obtained from this novel, including friendship, life struggle and persistence in work.This work was written by Hemingway in Cuba in 1951 for eight weeks. His writing style was very strong in the 20th century.

The Old Man and The Sea Novel has been translated into lots of language. In fact, in Indonesia, this novel was translated by 4 translators (Sapardi Djoko Damono, Yuni KP, Dian Vita, and Deera Army Pramana) with different publishers and lots of the translation's results. As a worldwide work which uses a different style than other works, his works is written in complex clauses. It affects the translation of Hemingway's work. A very literal translation especially on complex clauses such as Hemingway's work will affect the level of readability to be low or difficult to be understood.

One of the translation's result is The Old Man and The Sea published by the Narasi Publisher in 2015 (the first print), which was translated by Deera Army Pramana. It is chosen by the researcher for reference material because it is the newest translation from The Old Man and The Sea novel than others before. Even lots of words found in the translation of the novels are like Sapadi Djoko Damono's translation, but there is no translation of Novela The Old Man and The Sea by Deera Army Pramana. In addition, not many people study about this. On other hand, the result of Deera's translation is interesting and easy to be understood.

This translation choses a simpler style than the original style. Hemingway's writing style which uses a very long complex clause is diverted by translator style in the shorter text by dividing into several clauses. 
A clause which consists of more than 29 words such as the complex clause in Hemingway's works is difficult to be translated, the usual spliting technique in translation by decapitating one clause into two or more clauses to improve readability or by noticing that the reader does not have good readbility.

By looking at translation's case that greatly simplifies a very long clause complex, it is needed to read the translation about clause complex. This study can be used clearly by Systemic Functional Grammar.

Through ideational meaning metafunction at the logico level, Systemic Functional Grammar studies specifically recognize clause complex in terms of interdepandence and meaning. In terms of form, complex clauses are realized in the form of interdependence which is divided into 2: paratactic and hypotactic. In terms of meaning, complex clauses contain logico semantics: projection and expansion. Projection contains 2 meanings: locution which utilizes verbal processes symbolized by (") and ideas that utilize mental processes symbolized by ("). While expansion has 3 meanings: elaboration symbolized by (=), the extension by $(+)$, and the enhancement by $(x)$.

This Systemic Functional Grammar is expected to display linguistic evidence that has been systemically realized in the context of language. It is also expected to get a reason for the clause complex in the SL which is translated in the TL text.

In short, researcher is interested in analogizing complex clauses (taxis) on The Old Man and The Sea novel through functional linguistic systemics.

\section{LITERATURE REVIEW}

Basically, translation means the process of transferring messages, meanings, ideas, thoughts, or text. Translation experts provide definitions of translation in different ways but substantially contain the same purpose, except that there are differences in emphasis on each definition. Brislin looks more at the content of the text itself, namely the thoughts or ideas contained therein. Brislin (1986) argues that translation is a general term that refers to the transfer of thoughts or ideas from a language (source) into another language (target) both written and oral. Meanwhile, Catford is more concerned with translating text because the one that is translated is basically text. Catford (1974) defines translation as replacing text material in one language (source language) with text material that is commensurate with other languages (target language). In another part, Catford (1974) also says that translation is a work that is realized in language: a process of replacing text in one language to another in another language. The definition of similar translation is stated by Meethan and Hudson, that translation is the replacement of a text into the equivalent second language (in Bell, 1997). The definitions of Meethan \& Hudson and Catford are seen as more appropriate to underlie this study because of the emphasis on the text. The text is a unit of language that expresses meaning contextually (Wiratno, 2003,p. 3). In the transfer of text from one language to another, of course, the form changes cannot be avoided, even the style can be changed, including changes in the taxis (clause complex) pattern that is the focus of this study. Complex clauses contain more than one idea expressed in one clause. "Clauses can be divided into simplex clauses and complex clauses" (Halliday, 1994, p. 215). The simplex clause contains one clause, while the complex clause contains Head clause together with other clauses that modify it. Wiratno (2010) argues that the simplex clause is a clause that only contains one main process. The process in the sentence is indicated by the use of verbs. According to Gerot and Wignell (2013), taxis or interdependence shows the logical interrelationship between clauses in complex clauses, which indicate whether one clause depends on or dominates another, or whether the clause is equivalent. Taxis consists of two types, namely: paratactic and hypotactic. Paratactic is a logical interdependence between equal clauses, "the relationship between two elements is equal, one begins and the other continues" (Halliday, 2004, p. 374). Paratactically logical relationships are symmetrical and transitive. The clause in paratactic symbolized by numbers 1,2,3, etc. (Gerot and Wignell, 2013, p. 75). Hypotactic, in Halliday (2004) is "the binding of elements of unequal status clauses". Independent clause is a free element, while dependent clause is a bound element. Therefore, the hypothetical relationship is logically nonsymmetrical and non-transitive. In Gerot and Wignell (2013), hypothetical relationships between dominant and dependent units are marked in notation with Greek alphabet clause labels, using alpha $(\alpha)$ for independent clause, and beta $(\beta)$, gamma $(\gamma)$, delta $(\delta)$ for the dependent clause. And it should be emphasized that the independent clause $(\alpha)$ is not always at the beginning of the clause. The clauses in the complex clause are related not only in terms of taxis but also in terms of certain logico-semantic relationships. Halliday (2014) argues that based on fundamental relationships, logical semantics can be divided into two, namely expansion and projection. Elements related to expansion, secondary clauses retrieve messages from the primary clause and expand on them. This can be done in one of three ways, namely by elaboration, extension, and enhancement.

"Elaboration means a clause that develops another clause by describing it, restating it with a different sentence, or giving an example" (Halliday, 1994, p. 220).

Extension means one clause extends another clause by adding something new, giving an exception to it, or offering an alternative.

Enhancement means one clause develops another clause by providing some further information relating in a systematic way through the semantic features of time, cause, condition or concession.

Projection relationships differ from expansion. In elements related to projections, secondary clauses are stated by the main clause as something said (verbal expression) or something thought (idea). According to Halliday, in this type of expression, one clause is projected through another clause, as an expression, the construction of words. And, in the form 
of ideas, a clause is projected by another clause, which shows as an idea or construction of meaning. In other words, locution is projected verbally while ideas are projected by events as a result of thinking (Thompson, 1996, p. 27).

According to Halliday (1994) projection means secondary clauses are projected through the main clause. Projection is divided into two, namely locution and idea.

Locution means one clause is projected through another clause which presents it in the form of locution or speech construction.

Idea means a clause projected through another clause that presents it as an idea or construction of meaning.

In translating a text, the translator requires translation techniques. Machali (2000) says that there are 2 important things: (1) techniques are practical things; (2) techniques used in certain tasks. Because the techniques include practical things that can be developed through training, including translation, the translation techniques are more related to practical steps in solving translation problems. The following are translation techniques according to Molina and Albir (2002, p. 509-511).

a. Adaptation, this translation technique is used to replace elements of SL culture into TL cultural elements.

b. Amplification (Amplification), translation techniques that express messages explicitly or paraphrase the information implicit in SL.

c. Borrowing, translation techniques by borrowing words or meanings of SL, either as pure borrowing (pure borrowing) or naturalized borrowing (naturalized borrowing).

d. Calque (Calque) or Loan Translation, this translation technique refers to literal translation, both words, and phrases of TL.

e. Compensation, translation techniques that introduce elements of messages or information or the stylistic influence of TL text in SL text.

f. Description (Description), translation techniques to replace a term or meaning with a description both in form and function.

g. Discursive Creation, this translation technique is to make unexpected or out-of-context temporary equivalence. This technique is usually used in translating book titles or movie titles.

h. Establish Equivalent, this translation technique tends to use familiar terms or expressions (either in dictionaries or the use of everyday language).

i. Generalization, this translation technique tends to use more general or more neutral terms.

j. Linguistic Amplification (Linguistic Amplification), this technique is to add linguistic elements in the TL text, usually used in consecutive or dubbing interpretations.

k. Linguistic Compression, this technique utilizes the way to synthesize linguistic elements in the TL text which translators usually use in simultaneous translation and film text translation.

1. Literal Translation, this translation technique looks at the closest grammatical instructions in SL, but lexical translation or words are done separately from the context.

$\mathrm{m}$. Modulation, in this technique, there is a change in perspective, focus or cognitive category in relation to the source language.

n. Particularization (Particularization), translation techniques where translators use terms that are more concrete, precise or specific, from superordinates to subordinates. This technique is the opposite of generalization techniques.

o. Reduction, the technique is applied by partial removal because the removal is considered not to cause distortion of meaning. In other words, implicit-explicit information.

p. Substitution, this technique is done by changing linguistic and paralinguistic elements (intonation or cues).

q. Transposition, transposition is a translation technique by changing the grammatical category. This technique is similar to the technique of shifting categories, structures, and units.

R.Variation, the realization of this technique is to change linguistic or paralinguistic elements that affect linguistic variation: changes in textual tone, language style, social dialect, geographical dialect. This technique is commonly applied in translating drama scripts.

\section{ReSEARCh Methodology}

\section{A. Research Design and Strategies}

Since in this study an emphasis is given more on process problems than results, the form used in this study was descriptive qualitative in nature. The strategy employed in this study is a case study.

\section{B. Object of the Study}

The object of this research is the taxis (clause complex) translation of Ernest Hemingway's novel entitled The Old Man and the Sea translated by the translator Deera Army Pramana, into the same title, The Old Man and the Sea (not translated). The novel was published by the NARASI Publisher, Yogyakarta, in 2015.

\section{Data and Sources of the Data}

Data or information in this study are qualitative data. The data in this study are: 1) the taxis (clause complex) contained in the novel entitled The Old Man and the Sea and its translation, 2) the technique of the taxis (clause 
complex) and the quality of the translation of the equivalence of meaning, acceptance, and legibility of the translation text, 3) information about the reader's response to the legibility of the translation text of the novel entitled The Old Man and the Sea.

This information is obtained from various data sources, and the types of data sources that used in this study include written data sources (SL texts and TL text novels entitled The Old Man and the Sea) and informant, consist of linguists and a translator expert.

\section{Sampling Techniques}

The sampling technique used in this research is selective sampling technique. Researcher based on consideration of the theoretical concepts used, researchers' personal desires, empirical characteristics, and others. Therefore, the sampling technique employed is more "purposive sampling". In this research, the researcher chose a narrative genre by selecting data on semantic features of narrative texts that are intactly related to complex clauses, namely by considering the form and meaning; forms of interdependence (paratactic and hypotactic), and logico semantic (projection and expansion) meanings. However, due to limited time and energy, the researcher limits the amount of data, namely 100 clauses from the front, and 100 clauses from the back of the novels of The Old Man and the Sea.

\section{E. Method of Data Collection}

Because the form of this study is qualitative and data sources are utilized by written data sources and informant, the data collection techniques that used in this study are as follows:

1. Document Analysis (content analysis)

Content analysis is a scientific analysis of the content of a communication message (Barcus in Noeng Muhadjir, 2000, p. 68). This technique was employed to collect preliminary data from novel entitled The Old Man and the Sea, SL texts and TL texts. This technique was carried out with the following steps: reading the novel, then marking the clause complex and record on the data card. giving code to each data card, then classifying the taxis according to the type of problem and the last, reducing as well as analyzing the results of the study documents obtained.

2. Focus Group Discussion (FGD)

Focus Group Discussion (FGD) is increasingly being used as a method, technique and research instrument, including for assessment, planning, implementation, monitoring and evaluation development activities. The purpose of FGD is to get input or information about the problems that are local and specific. The data in this study were explored through FGD which involved: translation experts, linguists, translation experts, and researcher.

\section{F. Data Analysis Techniques}

Data analysis in this study was carried out from the initial stage of the research to the final stage of writing research results. Qualitative analysis means that the entire analysis is from collecting data, classifying data, connecting between categories, till interpreting the data based on context (Santosa, 2014, p. 64).

\section{RESULT AND ANALYSIS}

TABLE 4.1

PERCENTAGE OF FORMS OF TAXIS IN EACH STAGE IN THE TRANSLATION OF THE OLD MAN AND THE SEA NOVEL

\begin{tabular}{|l|l|l|l|}
\hline Staging & Taxis & Total & Percentage \\
\hline \multirow{5}{*}{ Orientation } & Paratactic extension & 104 & $14,8 \%$ \\
\cline { 2 - 4 } & Paratactic locution & 54 & $7,7 \%$ \\
\cline { 2 - 4 } & Paratactic idea & 4 & $0,6 \%$ \\
\cline { 2 - 4 } & Hypotactic elaboration & 36 & $5,1 \%$ \\
\cline { 2 - 4 } & Hypotactic enhancement & 47 & $6,7 \%$ \\
\cline { 2 - 4 } & Hypotactic locution & 1 & $0,1 \%$ \\
\hline \multirow{5}{*}{ Ronflict } & Paratactic extension & 90 & $12,8 \%$ \\
\cline { 2 - 4 } & Paratactic locution & 15 & $2,1 \%$ \\
\cline { 2 - 4 } & Paratactic idea & 15 & $2,1 \%$ \\
\cline { 2 - 4 } & Paratactic elaboration & 10 & $1,4 \%$ \\
\cline { 2 - 4 } & Paratactic enhancement & 6 & $0,9 \%$ \\
\cline { 2 - 4 } & Hypotactic enhancement & 30 & $4,3 \%$ \\
\cline { 2 - 4 } & Hypotactic elaboration & 24 & $3,4 \%$ \\
\hline & Paratactic extension & 105 & $15 \%$ \\
\cline { 2 - 4 } & Paratactic locution & 27 & $3,9 \%$ \\
\cline { 2 - 4 } & Paratactic idea & 26 & $3,7 \%$ \\
\cline { 2 - 4 } & Paratactic enhancement & 2 & $0,3 \%$ \\
\cline { 2 - 4 } & Hypotactic idea & 3 & $0,4 \%$ \\
\cline { 2 - 4 } & Hypotactic elaboration & 44 & $6,3 \%$ \\
\cline { 2 - 3 } & Hypotactic extension & 3 & $0,4 \%$ \\
\hline & Hypotactic enhancement & 55 & $7,8 \%$ \\
\hline & & & \\
\hline
\end{tabular}


Based on the data analysis, there are 400 sentences divided into 701 clauses. Every existing data have been identified to produce several types of interdependence and logical meaning at the stages of orientation, conflict and resolution in The Old Man and the Sea novel, including paratactic extension, hypotactic elaboration, paratactic idea, hypotactic enhancement.

Based on the results of research that has been done, paratactic extension was a taxis which was widely found. At the orientation stage, 104 paratactic extension taxis was found with a percentage of $14.8 \%$. In the conflict section, 90 paratactic extension with a percentage of $12.8 \%$. Meanwhile in the resolution section there are 105 paratactic extension with a percentage of $15 \%$.

Paratactic is often found because it is a logical interdependence between equal clauses, "the relationship between two elements is equal, one begins and the other continues" (Halliday, 1994, p. 218), so the taxis are easier to understand. Extension means one clause extends another clause by adding something new, giving an exception to it, or offering an alternative. This makes the taxis more accurate and more easily accepted.

a. Paratactic is a logical interdependence between equal clauses, "the relationship between two elements is equal, one begins and the other continues" (Halliday, 1994, p. 218). Paratactically logical relationships are symmetrical and transitive. The clause in paratactic is symbolized by numbers 1, 2, 3, etc. (Gerot and Wignell, 1995). Based on the table above, there is a paratactic extension in three stages. The first is 104 the extension tactics with the percentage of $14.8 \%$ in the orientation section. The second is paratactic extension with the number of 90 with a percentage of $12.8 \%$ in the conflict section. Paratactic extension amounts to 105 with the percentage of $15 \%$ in the resolution section; there are 10 elaboration paratactic with percentage of $1.4 \%$ in the conflict section; there are enhancement paratactic in two stages. There are 6 enhancement paratactic with a percentage of $0.9 \%$ in the conflict section. There are 2 enhancement paratactic with a percentage of $0.3 \%$ in the resolution section; there is a localization paratactic in three stages. 54 locution paratactic with a percentage of $7.7 \%$ are in the orientation section. 15 locution paratactic with a percentage of $2.1 \%$ are in the conflict section. 27 locution paratactic with a percentage of $3.9 \%$ are in the resolution section; there is a paratactic idea in three stages. 4 Paratactic ideas with a percentage of $0.6 \%$ are in the orientation section. 15 Paratactic extensions with a percentage of $2.1 \%$ are in the conflict section. 26 Paratactic extensions with a $3.7 \%$ percentage are in the resolution section.

b. Hypotactic is "the binding of elements of unequal status clauses"(Halliday, 1994, p. 221). Independent clause is a free element, while dependent clause is a bound element. Therefore, the hypothetical relationship is logically nonsymmetrical and non-transitive. In Gerot and Wignell (1995: 75), hypothetical relationships between dominant and dependent units are marked in notation with Greek alphabet clause labels, using alpha $(\alpha)$ for independent clause, and beta $(\beta)$, gamma $(\gamma)$, delta $(\delta)$ for dependent clause. Based on the table above, there are 3 hypotactic extensions with a percentage of $0.4 \%$ in the resolution section; there is a hypothetical elaboration in three stages. In the orientation section there are 36 elaboration hypotheses with a percentage of $5.1 \%$; in the 24 th part of the conflict with a percentage of $3.4 \%$, and in the resolution section there are 44 or $6.3 \%$; there is hypothetical sensitivity in three stages. In the orientation section there are 47 hypothetical sensitivities with a percentage of $6.7 \%$. In the conflict section, there are 30 hypothetical sensitivities (4.3\%) in the resolution section, and immune hypotheses or 7.8\%; there are 3 hypotactic idea with a percentage of $0.4 \%$ in the resolution section; there is a hypotactic locution of 1 with a percentage of $0.1 \%$ in the orientation section.

TABLE 4.2

PERCENTAGE OF TECHNIQUE IN EACH STAGE IN THE TRANSLATION OF THE OLD MAN AND THE SEA NOVEL

\begin{tabular}{|c|c|c|c|c|}
\hline Staging & Taxis & Technique & Total & Percentage \\
\hline \multirow{23}{*}{ Orientation } & Paratactic Extension & & & \\
\hline & \multirow{6}{*}{ a. And } & 1. Establish equivalent & 46 & $6,56 \%$ \\
\hline & & 2. Deletion & 27 & $3,85 \%$ \\
\hline & & 3. Explicit & 9 & $1,28 \%$ \\
\hline & & 4. Implicit & 4 & $0,57 \%$ \\
\hline & & 5. Transposition & 1 & $0,14 \%$ \\
\hline & & 6. Modulation & 1 & $0,14 \%$ \\
\hline & \multirow{3}{*}{ b. But } & 1. Establish equivalent & 11 & $1,57 \%$ \\
\hline & & 2. Transposition & 2 & $0,29 \%$ \\
\hline & & 3. Explicit & 1 & $0,14 \%$ \\
\hline & \multirow{2}{*}{ c. Or } & 1. Deletion & 1 & $0,14 \%$ \\
\hline & & 2. Discursive creation & 1 & $0,14 \%$ \\
\hline & \multicolumn{4}{|l|}{ Paratactic Locution } \\
\hline & \multirow{5}{*}{ a. Said } & 1. Establish equivalent & 30 & $4,28 \%$ \\
\hline & & 2. Deletion & 1 & $0,14 \%$ \\
\hline & & 3. Transposition & 13 & $1,85 \%$ \\
\hline & & 4. Explicit & 4 & $0,57 \%$ \\
\hline & & 5. Implicit & 1 & $0,14 \%$ \\
\hline & \multirow{3}{*}{ b. Asked } & 1. Establish equivalent & 1 & $0,14 \%$ \\
\hline & & 2. Transposition & 1 & $0,14 \%$ \\
\hline & & 3. Deletion & 1 & $0,14 \%$ \\
\hline & c. Explained & 1. Establish equivalent & 1 & $0,14 \%$ \\
\hline & d. Told & 1. Transposition & 1 & $0,14 \%$ \\
\hline
\end{tabular}




\begin{tabular}{|c|c|c|c|c|}
\hline & Paratactic Idea & & & \\
\hline & a. Agreed & 1. Establish equivalent & 1 & $0,14 \%$ \\
\hline & b. Thought & 1. Transposition & 2 & $0,29 \%$ \\
\hline & c. Think & 1. Transposition & 1 & $0,14 \%$ \\
\hline & Hypotactic Locution & & & \\
\hline & a. Say & 1. Establish equivalent & 1 & $0,14 \%$ \\
\hline & Hypotactic Elaboration & & & \\
\hline & & 1. Establish equivalent & 1 & $0,14 \%$ \\
\hline & a. Who & 2. Explicit & 1 & $0,14 \%$ \\
\hline & & 1. Establish equivalent & 18 & $2,57 \%$ \\
\hline & & 2. Explicit & 1 & $0,14 \%$ \\
\hline & b. That & 3. Deletion & 2 & $0,29 \%$ \\
\hline & & 4. Implicit & 1 & $0,14 \%$ \\
\hline & c. What & 1. Establish equivalent & 2 & $0,29 \%$ \\
\hline & & 1. Establish equivalent & 2 & $0,29 \%$ \\
\hline & d. Where & 2. Literal & 2 & $0,29 \%$ \\
\hline & & 1. Establish equivalent & 2 & $0,29 \%$ \\
\hline & e. Which & 2. Explicit & 1 & $0,14 \%$ \\
\hline & f. How & 1. Literal & 1 & $0,14 \%$ \\
\hline & g. Whether & 1. Establish equivalent & 1 & $0,14 \%$ \\
\hline & h. As & 1. Establish equivalent & 1 & $0,14 \%$ \\
\hline & Hypotactic Enhancement & & & \\
\hline & & 1. Explicit & 1 & $0,14 \%$ \\
\hline & & 2. Establish equivalent & 4 & $0,57 \%$ \\
\hline & a. Then & 3. Implicit & 1 & $0,14 \%$ \\
\hline & & 4. Deletion & 1 & $0,14 \%$ \\
\hline & b. And though & 1. Deletion & 1 & $0,14 \%$ \\
\hline & c. So that & 1. Establish equivalent & 1 & $0,14 \%$ \\
\hline & d. As & 1. Establish equivalent & 3 & $0,43 \%$ \\
\hline & & 1. Establish equivalent & 3 & $0,43 \%$ \\
\hline & e. If & 2. Deletion & 1 & $0,14 \%$ \\
\hline & f. So & 1. Transposition & 1 & $0,14 \%$ \\
\hline & & 1. Establish equivalent & 14 & $1,99 \%$ \\
\hline & & 2. Explicit & 1 & $0,14 \%$ \\
\hline & g. When & 3. Deletion & 1 & $0,14 \%$ \\
\hline & & 4. Modulation & 2 & $0,29 \%$ \\
\hline & & 5. Discursive creation & 1 & $0,14 \%$ \\
\hline & h. Before & 1. Establish equivalent & 1 & $0,14 \%$ \\
\hline & i. Where & 1. Literal & 1 & $0,14 \%$ \\
\hline & j. While & 1. Transposition & 1 & $0,14 \%$ \\
\hline & & 1. Discursive creation & 2 & $0,29 \%$ \\
\hline & k. And then & 2. Establish equivalent & 2 & $0,29 \%$ \\
\hline & & 3. Explicit & 1 & $0,14 \%$ \\
\hline & 1. Because & 1. Establish equivalent & 3 & $0,43 \%$ \\
\hline & Paratactic Extension & & & \\
\hline & & 1. Establish equivalent & 73 & $10,41 \%$ \\
\hline & & 2. Transposition & 4 & $0,57 \%$ \\
\hline & a. And & 3. Deletion & 4 & $0,57 \%$ \\
\hline & & 4. Implicit & 2 & $0,29 \%$ \\
\hline & & 5. Explicit & 1 & $0,14 \%$ \\
\hline & b. But & 1. Establish equivalent & 3 & $0,43 \%$ \\
\hline & c. Nor & 1. Establish equivalent & 2 & $0,29 \%$ \\
\hline & d. Or & 1. Establish equivalent & 1 & $0,14 \%$ \\
\hline & Paratactic Locution & & & \\
\hline & & 1. Establish equivalent & 7 & $0,99 \%$ \\
\hline & a. Said & 2. Transposition & 7 & $0,99 \%$ \\
\hline & & 3. Implicit & 1 & $0,14 \%$ \\
\hline Conflict & Paratactic Idea & & & \\
\hline Conflict & & 1. Transposition & 12 & $1,71 \%$ \\
\hline & a. Thought & 2. Establish equivalent & 2 & $0,29 \%$ \\
\hline & b. Remembered & 1. Establish equivalent & 1 & $0,14 \%$ \\
\hline & Paratactic Elaboration & & & \\
\hline & & 1. Establish equivalent & 5 & $0,71 \%$ \\
\hline & Thet & 2. Transposition & 1 & $0,14 \%$ \\
\hline & a. That & 3. Implicit & 1 & $0,14 \%$ \\
\hline & & 4. Modulation & 1 & $0,14 \%$ \\
\hline & b. What & 1. Establish equivalent & 1 & $0,14 \%$ \\
\hline & c. Without & 1. Establish equivalent & 1 & $0,14 \%$ \\
\hline & Paratactic Enhancement & & & \\
\hline & a. And then & 1. Establish equivalent & 3 & $0,43 \%$ \\
\hline & b. So that & 1. Establish equivalent & 2 & $0,29 \%$ \\
\hline & c. So & 1. Establish equivalent & 1 & $0,14 \%$ \\
\hline
\end{tabular}




\begin{tabular}{|c|c|c|c|c|}
\hline & Hypotactic Enhancement & & & \\
\hline & - & 1. Establish equivalent & 4 & $0,57 \%$ \\
\hline & a. When & 2. Explicit & 1 & $0,14 \%$ \\
\hline & b. For & 1. Establish equivalent & 1 & $0,14 \%$ \\
\hline & c Весаисе & 1. Establish equivalent & 1 & $0,14 \%$ \\
\hline & c. Because & 2. Implicit & 1 & $0,14 \%$ \\
\hline & d. If & 1. Establish equivalent & 6 & $0,86 \%$ \\
\hline & e. How & 1. Establish equivalent & 1 & $0,14 \%$ \\
\hline & 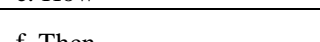 & 1. Establish equivalent & 1 & $0,14 \%$ \\
\hline & t. Then & 1. Explicit & 1 & $0,14 \%$ \\
\hline & & 1. Establish equivalent & 2 & $0,29 \%$ \\
\hline & g. While & 2. Explicit & 1 & $0,14 \%$ \\
\hline & h. So that & 1. Establish equivalent & 2 & $0,29 \%$ \\
\hline & i. Until & 1. Establish equivalent & 2 & $0,29 \%$ \\
\hline & j. Before & 1. Establish equivalent & 3 & $0,43 \%$ \\
\hline & k. After & 1. Establish equivalent & 1 & $0,14 \%$ \\
\hline & 1. That & 1. Establish equivalent & 2 & $0,29 \%$ \\
\hline & Hypotactic Elaboration & & & \\
\hline & & 1. Establish equivalent & 9 & $1,28 \%$ \\
\hline & & 2. Explicit & 3 & $0,43 \%$ \\
\hline & a. That & 3. Literal & 1 & $0,14 \%$ \\
\hline & & 4. Implicit & 1 & $0,14 \%$ \\
\hline & & 5. Modulation & 1 & $0,14 \%$ \\
\hline & b. Where & 1. Establish equivalent & 2 & $0,29 \%$ \\
\hline & & 1. Literal & 1 & $0,14 \%$ \\
\hline & c. As & 2. Modulation & 1 & $0,14 \%$ \\
\hline & & 3. Establish equivalent & 1 & $0,14 \%$ \\
\hline & d. Though & 1. Establish equivalent & 1 & $0,14 \%$ \\
\hline & e. What & 1. Establish equivalent & 2 & $0,29 \%$ \\
\hline & f. If & 1. Establish equivalent & 1 & $0,14 \%$ \\
\hline & Paratactic Extension & & & \\
\hline & & 1. Establish equivalent & 73 & $10,41 \%$ \\
\hline & & 2. Modulation & 1 & $0,14 \%$ \\
\hline & a. And & 3. Deletion & 9 & $1,28 \%$ \\
\hline & & 4. Implicit & 4 & $0,57 \%$ \\
\hline & & 5. Explicit & 6 & $0,86 \%$ \\
\hline & b Put & 1. Establish equivalent & 6 & $0,86 \%$ \\
\hline & b. But & 2. Transposition & 2 & $0,29 \%$ \\
\hline & c. Nor & 1. Establish equivalent & 1 & $0,14 \%$ \\
\hline & $\mathrm{d}_{\mathrm{S}}$ & 1. Establish equivalent & 1 & $0,14 \%$ \\
\hline & d. so & 2. Deletion & 1 & $0,14 \%$ \\
\hline & e. Or & 1. Establish equivalent & 1 & $0,14 \%$ \\
\hline & Paratactic Locution & & & \\
\hline & Soid & 1. Establish equivalent & 11 & $1,57 \%$ \\
\hline & a. sald & 2. Transposition & 16 & $2,28 \%$ \\
\hline & Paratactic Idea & & & \\
\hline & & 1. Transposition & 18 & $2,57 \%$ \\
\hline & & 2. Establish equivalent & 5 & $0,71 \%$ \\
\hline & a. Thought & 3. Deletion & 1 & $0,14 \%$ \\
\hline & & 4. Paraphrase & 1 & $0,14 \%$ \\
\hline Docolution & b. Said & 1. Establish equivalent & 1 & $0,14 \%$ \\
\hline Kesoitution & Hypotaktik Elaboration & & & \\
\hline & & 1. Establish equivalent & 23 & $3,28 \%$ \\
\hline & & 2. Transposition & 2 & $0,29 \%$ \\
\hline & a. That & 3. Implicit & 6 & $0,86 \%$ \\
\hline & & 4. Deletion & 2 & $0,29 \%$ \\
\hline & & 5. Explicit & 1 & $0,14 \%$ \\
\hline & b. What & 1. Establish equivalent & 1 & $0,14 \%$ \\
\hline & c. How & 1. Establish equivalent & 1 & $0,14 \%$ \\
\hline & c. How & 2. Modulation & 1 & $0,14 \%$ \\
\hline & d. Who & 1. Establish equivalent & 1 & $0,14 \%$ \\
\hline & Where & 1. Establish equivalent & 1 & $0,14 \%$ \\
\hline & e. Where & 2. Literal & 1 & $0,14 \%$ \\
\hline & f. Such as & 1. Establish equivalent & 1 & $0,14 \%$ \\
\hline & g. If & 1. Establish equivalent & 1 & $0,14 \%$ \\
\hline & h. As & 1. Establish equivalent & 1 & $0,14 \%$ \\
\hline & i. Which & 1. Deletion & 1 & $0,14 \%$ \\
\hline & Paratactic Enhancement & & & \\
\hline & a. And then & 1. Explicit & 1 & $0,14 \%$ \\
\hline & b. If & 1. Establish equivalent & 1 & $0,14 \%$ \\
\hline & Hypotactic Enhancement & & & \\
\hline & a. When & 1. Establish equivalent & 8 & $1,14 \%$ \\
\hline
\end{tabular}




\begin{tabular}{|c|c|c|c|}
\hline & 2. Explicit & 1 & $0,14 \%$ \\
\hline & 3. Modulation & 1 & $0,14 \%$ \\
\hline b. For & 1. Establish equivalent & 1 & $0,14 \%$ \\
\hline \multirow{2}{*}{ c. Because } & 1. Establish equivalent & 3 & $0,43 \%$ \\
\hline & 2. Implicit & 1 & $0,14 \%$ \\
\hline \multirow{3}{*}{ d. If } & 1. Establish equivalent & 5 & $0,71 \%$ \\
\hline & 2. Deletion & 1 & $0,14 \%$ \\
\hline & 3. Literal & 1 & $0,14 \%$ \\
\hline e. Beside & 1. Establish equivalent & 1 & $0,14 \%$ \\
\hline f. Then & 1. Establish equivalent & 6 & $0,86 \%$ \\
\hline g. Eventhough & 1. Establish equivalent & 1 & $0,14 \%$ \\
\hline \multirow{4}{*}{ h. As } & 1. Establish equivalent & 10 & $1,43 \%$ \\
\hline & 2. Discursive creation & 1 & $0,14 \%$ \\
\hline & 3. Modulation & 2 & $0,29 \%$ \\
\hline & 4. Literal & 1 & $0,14 \%$ \\
\hline i. So & 1. Deletion & 1 & $0,14 \%$ \\
\hline j. Until & 1. Establish equivalent & 1 & $0,14 \%$ \\
\hline k. Even if & 1. Establish equivalent & 1 & $0,14 \%$ \\
\hline 1. Where & 1. Establish equivalent & 1 & $0,14 \%$ \\
\hline m. After & 1. Establish equivalent & 1 & $0,14 \%$ \\
\hline n. That & 1. Establish equivalent & 3 & $0,43 \%$ \\
\hline o. While & 1. Establish equivalent & 2 & $0,29 \%$ \\
\hline p. Before & 1. Establish equivalent & 1 & $0,14 \%$ \\
\hline \multicolumn{4}{|l|}{ Hypotactic Idea } \\
\hline a. Felt & 1. Establish equivalent & 1 & $0,14 \%$ \\
\hline b. Promised & 1. Implicit & 1 & $0,14 \%$ \\
\hline c. Though & 1. Establish equivalent & 1 & $0,14 \%$ \\
\hline Hypotactic Extension & & & \\
\hline a. Except & 1. Establish equivalent & 1 & $0,14 \%$ \\
\hline b. Also & 1. Establish equivalent & 1 & $0,14 \%$ \\
\hline c. And & 1. Establish equivalent & 1 & $0,14 \%$ \\
\hline
\end{tabular}

a) Establish Equivalent, this common equivalent technique has an overall percentage of $67.41 \%$ with $20.25 \%$ in the orientation stage, $20.54 \%$ in the conflict stage and $25.62 \%$ at the resolution stage.

b) Excitation, this exploitation technique has an overall percentage of $5.10 \%$ with $2.83 \%$ in the orientation stage, $0.99 \%$ in the conflict stage and $1.28 \%$ at the resolution stage.

c) Discursive Creation, this discursive creation technique has an overall percentage of $0.71 \%$ with $0.57 \%$ at the orientation stage and $0.14 \%$ at the resolution stage.

d) Modulation, this modulation technique has an overall percentage of $1.56 \%$ with $0.43 \%$ in the orientation stage, $0.42 \%$ in the conflict stage and $0.71 \%$ in the resolution stage.

e) Transposition, this transposition technique has an overall percentage of $12.11 \%$ with $3.27 \%$ in the orientation stage, $3.41 \%$ in the conflict stage and $5.43 \%$ at the resolution stage.

f) Deletion, this deletion technique has an overall percentage of $7.82 \%$ with $4.98 \%$ in the orientation stage, $0.57 \%$ in the conflict stage and $2.27 \%$ at the resolution stage.

g) Literal, this literal technique has an overall percentage of $1.27 \%$ with $0.57 \%$ in the orientation stage, $0.28 \%$ in the conflict stage and $0.42 \%$ in the resolution stage.

Based on the table above, establish equivalent is the most translation technique that often used. This translation technique tends to use familiar terms or expressions (either in dictionaries or the use of everyday language).

\section{Conclusion}

Based on data analysis and discussion, some conclusions can be drawn as follows. Based on the data analysis, it is found several types of interdependence and logical meanings are contained in the translation of The Old Man and The Sea novel, including:

a) Paratactic

Based on the results of data analysis, the total paratactic percentage was $65.30 \%$ with $23.10 \%$ in the orientation stage, $19.30 \%$ in the conflict stage and $23 \%$ at the resolution stage. One example of a paratactic form is that He reached out for the line and held it softly between the thumb and forefinger of his right hand which was translated into Ia meraih tali kail itu dan menahannya dengan lembut di antara jempol dan jari telunjuk tangan kanannya.

b) Hypotactic

Based on the results of the data analysis, the overall hypotactic percentage was $34.50 \%$ with $11.90 \%$ in the orientation stage, $7.70 \%$ in the conflict stage and $14.90 \%$ at the resolution stage. An example of hypotactic form is One hundred fathoms down a marlin was eating the sardines that covered the point and the shank of the hook where the hand-forged hook projected from the head of the small tuna which is translated into Seratus fatom di bawah sana seekor ikan marlin tengah memangsa sarden yang menutupi ujung dan tangkai mata kail di mana mata kail tempaan tangan mencuat dari kepala tuna kecil. 
There are seven translation techniques that used in this research. Establish equivalent technique is the most translation technique that often used. This translation technique tends to use familiar terms or expressions (either in dictionaries or the use of everyday language). This common equivalent technique has an overall percentage of $67.41 \%$ with $20.25 \%$ in the orientation stage, $20.54 \%$ in the conflict stage and $25.62 \%$ at the resolution stage.

\section{REFERENCES}

[1] Alwasilah, A. Chaedar. (1984). Linguistik: Suatu Pengantar. Bandung: Penerbit Angkasa.

[2] Baker, Mona. (2011). In other Word: a Course Book on Translation (2 Ed). London: Routledge.

[3] Bassnett, Susan. (1991). Translation Studies. London \& New York: Routledge.

[4] Bell, Roger T. (1997). Translating and Translation. Singapore: Longman Singapore Publisher.

[5] Bloor, Thomas and Bloor, Meriel. (2004). The Functional Analysis of English. London: Arnold. Available at http://en.bookfi.net/book/1443022 (accessed 31/01/2017).

[6] Bodgan, Robert and Tylor, Steven J. (1975). Introduction to Qualitative Research Methods. New York: John Wiley and Sons.

[7] Brislin, R. W. (1986) The Wording and Translation of Research Instruments. In: W. J. Lonner \& J. W. Berry (Eds.) Field Methods in Cross-Cultural Research. Beverly Hills: Sage Publications

[8] Cann, Ronnie. (1993). Formal Semantics. Great Britain: Cambridge University Press.

[9] Catford, J. C. (1974). A Linguistic Theory of Translation. Great Britain: Oxford University Press.

[10] Cruse, D. A. (1997). Lexical Semantics. Cambridge: University Press.

[11] Eggins, S. (2004). An Introduction to Systemic Functional Linguistics. London: Continuum.

[12] Gerot, Linda and Wignell, Peter. (2013). Making Sense of Functional Grammar, edited by Berti Nurul Khajati. Bekasi: STKIP Panca Sakti.

[13] Halliday, M.A.K. (2000). An Introduction to Functional Grammar. Beijing: Foreign Language Teaching and Research Press.

[14] Halliday, M.A.K. (2004). An Introduction to Functional Grammar.3rd Ed, revised by C. M.I.M. Matthiessen. London: Arnold.

[15] Irwanto. (2006). Focus Group Discussion (FGD): Sebuah Pengantar Praktis, Yayasan Obor Indonesia, Jakarta.

[16] Jacobs, R. A. (1995). English Syntax: A Grammar for English Language Professionals. New York: Oxford University Press.

[17] Kridalaksana, Harimurti. (1993). Kamus Linguistik. Jakarta: PT Gramedia.

[18] Larson, Mildred L. (1898). Penerjemahan Berdasar Makna: Pedoman untuk Pemadanan Antarbahasa (edisi terjemahan). Jakarta: Penerbit Arcan.

[19] Leech, Geoffrey. (1976). Semantics. Middlesex: Penguin Books Ltd.

[20] Machali, Rochayah. (2000). Pedoman Bagi Penerjemah. Jakarta. P.T.Grasindo Gramedia Widiasarana.

[21] Martin, J. R. (1992). English Text System and Structure. Philadelphia: John Benjamis Publishing Company.

[22] Moloeng, Lexy J. (2000). Metodologi Penelitian Kualitatif. Bandung: PT Remaja Rosdakarya.

[23] Morley, G. D. (2000). Syntax in Functional Grammar. New York: Continum Wellington House.

[24] Nababan, M. Rudolf. (1997). Aspek Teori Penerjemahan dan Pengalihbahasaan. Surakarta.

[25] Nababan, M. R. (2003). Teori Menerjemah Bahasa Inggris. Yogyakarta: Pustaka Pelajar.

[26] Nababan, M. R. (2004). "Translation Processes, Practices and Products of Professional Indonesian Translators. Unpublished Doctorate Dissertation. Schools of Linguistics and Applied Language Studies, Victoria University of Wellington, New Zealand.

[27] Nababan, M.R., Nuraeni \& Sumardiono. (2012). Pengembangan Model Penilaian Kualitas Terjemahan. Surakarta: Universitas Sebelas Maret Surakarta.

[28] Nida, Eugene A. (1969). Science of Translating. In Pym, Anthony. (1992). Translation and Text Transfer An Essay on the Principles of Intercurtural Communication. New York: Peterlang.

[29] Nida, Eugene A. (1975). Language Structure and Translation. California: Stanford University Press.

[30] Nida, Eugene A. (1975). Componential Analysis of Meaning: An Introduction to Semantic Structure. The Hague: The Netherlands Mouton \& Co. NV. Publishers.

[31] Noeng Muhadjir. (2000). Metode Penelitian Kualitatif. Yogyakarta: Penerbit Rake Sarasin.

[32] Patton. (1983). Qualitative Evaluation Methods. London: Sage Publication.

[33] Pym, Anthony. (1992). Translation and Text Transfer An Essay on the Principles of Intercurtural Communication. New York: Peterlang.

[34] Sadnoto, E. (1985). Pedoman Penerjemahan. Jakarta: Pusat Pengembangan dan Pengembangan Bahasa Departemen Pendidikan dan Kebudayaan.

[35] Sakri, Adjad. (1993). Bangun Kalimat Bahasa Indonesia. Bandung: Penerbit ITB Bandung.

[36] Santosa, Riyadi. (2001). Bahasa dalam Pandangan Semiotika Sosial. Surakarta: Universitas Sebelas Maret.

[37] Soemarno, Thomas. (1988). Hubungan Antara Lama Belajar dalam Bidang Penerjemahan, Jenis Kelamin, Kemampuan Berbahasa Inggris, dan Tipe-ipe Kesilapan Terjemahan dari Bahasa Inggris ke dalam Bahasa Indonesia. Malang: IKIP.

[38] Soemarno, Thomas. (1999). "Makna dalam Penerjemah". Dalam Seminar Nasional Semantik I, Surakarta.

[39] Spradley, James P. (1980). Participant Observation. New York: Holt, Rinehart and Winston.

[40] Sudarno, V. (1998). Penerjemahan Idiom dalam Bahasa Inggris. Surakarta: Universitas Sebelas Maret Surakarta.

[41] Sutopo, Heribertus B. (1996). Metodologi Penelitian Kualitatif. Surakarta: Universitas Sebelas Maret Surakarta.

[42] Sutopo, H. B. (2006). Penelitian Kualitatif: Dasar Teori dan Terapannya dalam Penelitian; Surakarta: UNS Surakarta

[43] Thompson, G. (1996). Introducing Functional Grammar. Oxford: Oxford University Press Inc.

[44] Ulman, Stephen. (1962). Semantics An Introduction to the Science of Meaning. Basil Blackwell. Oxford.

[45] Verhaar, J.W.M. (2010). Asas-Asas Linguistik Umum. Yogyakarta: Gadjah Mada University Press.

[46] Wiratno, T. (2003). Kiat Menulis Karya Ilmiah dalam Bahasa Inggris. Yogyakarta: Pustaka Pelajar. 
Arso Setyaji is currently pursuing his doctoral degree in Linguistics Department, Universitas Sebelas Maret, Surakarta, Indonesia with special concerns on translation.

Sri Samiati Tarjana is currently a member of Linguistics Department, Universitas Sebelas Maret, Surakarta, Indonesia. She acquired her master degree in TESOL from Victoria University of of Wellington. Her interests are on Pragmatics.

Mangatur Nababan is currently a member of Linguistics Department, Universitas Sebelas Maret, Surakarta, Indonesia. He obtained his master degree in Cuin/Reading and Language Arts from University of Houston Texas, master degree in Applied Linguistics and Ph.D in Applied Linguistics (Translation) from Victoria University of Wellington. His interests are on Translation studies.

Tri Wiratno is currently a member of Linguistics Department, Universitas Sebelas Maret, Surakarta, Indonesia. He received his master degree in Linguistics from University of Sydney. His interests are on Linguistics. 